\section{Paper Titles}

Comparison of Commercially Pure Titanium Surface Hardness Improvement by Plasma

Nitrocarburizing and Ion Implantation p.347

Effect of Phenolic Resin and Alignment to the Quality of Prototype Composite Railway Brake Blocks p.352

Effects of Welding Parameters in Micro Friction Stir Lap Welding of Aluminum A1100

p.356

Preparation of Uranium Nitride from Uranium Metal through by Hydriding and Nitriding Process

p.360

Simulation of Metal Flow to Investigate the Application of Antilock Brake Mechanic System in Deep Drawing Process of Cup p.367

Effect of Equal Channel Angular Pressing and Post Heating on Microstructure and Hardness of $\mathrm{Cu}$ Zn $70 / 30$

p.373

Materials Selection in Appropriate Technology Four Focuses in Design

Thinking

p.379

Study about Surface Hardening on Local Disc Brakes with Direct Current Plasma Nitrocarburizing Apparatus p.383

The Effect of Vertical Step Block Casting to Microstructure and Mechanical Properties in Producing Thin Wall Ductile Iron p.387

Home Advanced Materials Research Advances in Materials, Processing and... Simulation of Metal Flow to Investigate the...

\title{
Simulation of Metal Flow to Investigate the Application of Antilock Brake Mechanic System in Deep Drawing Process of $\mathrm{Cu}$
}

Abstract:

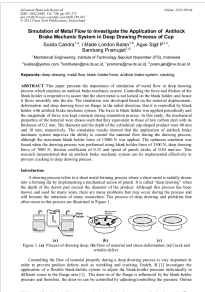

This paper presents the importance of simulation of metal flow in deep drawing process which employs an antilock brake mechanic system. Controlling the force and friction of $t$ blank holder is imperative to assure that the sheet metal is not locked on the blank hold and hence it flows smoothly into the die. The simulation was developed based on the material displacement, deformation and deep drawing force on flange in the radial direction, that it is controlled by blank holder with antilock brake mechanic system. The force to blank holder was applied periodically and the magnitude of force was kept constant during simulation process. In this study, the mechanical properties of the material were choses such that they equivalent to those of low carbon steel with its thickness of $0.2 \mathrm{~mm}$. The diameter and the depth of the cylindrical cup-shaped product were $40 \mathrm{~mm}$ and 10 $\mathrm{mm}$, respectively. The simulation results showed that the application of antilock brake mechanic system improves the ability to control the material flow during the drawing process, although the maximum blank holder force of $13000 \mathrm{~N}$ was applied. The optimum condition was found when the drawing process was performed using blank holder force of $3500 \mathrm{~N}$, deep drawing force of $7000 \mathrm{~N}$, friction coefficient of 0.25 and speed of punch stroke of $0.84 \mathrm{~mm} / \mathrm{sec}$. This research demonstrated that an antilock brake mechanic system ci be implemented effectively to prevent cracking in deep drawing process.

Info:

Periodical:

Main Theme:

Edited by:

Pages:

DOI:

Citation:

Online since:

Authors:

Keywords:

Export:

Price:

Permissions:

Share:
Advanced Materials Research (Volume 789)

\section{Advances in Materials, Processing and Manufacturing}

Akhmad Herman Yuwono

367-372

10.4028/www.scientific.net/AMR.789.367

S. Candra et al., "Simulation of Metal Flow to Investigate the Application of

Antilock Brake Mechanic System in Deep Drawing Process of Cup", Advanced Materials Research, Vol. 789, pp. 367-372, 2013

September 2013

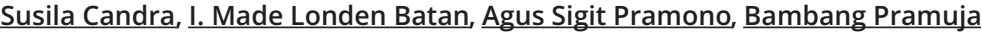

Antilock Brake System, Blank Holder Force, Cracking, Deep Drawing, Metal Flow

$\underline{\text { RIS, BibTeX }}$

$\$ 38.00$

$\underline{\text { Request Permissions }}$

f

References

Cited by 


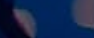

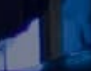

\section{Periodicals}

\section{Engineering Research}

Advanced Engineering Forum

Journal of Biomimetics, Biomaterials and Biomedical Engineering

Advances in Science and Technology

Applied Mechanics and Materials

International Journal of Engineering Research in Africa

Foundations of Materials Science and Engineering

\section{Materials Science}

Journal of Metastable and Nanocrystalline Materials

Journal of Nano Research

Defect and Diffusion Forum

Solid State Phenomena

Diffusion Foundations

Materials Science Forum

Key Engineering Materials

Nano Hybrids and Composites

Advanced Materials Research

\section{Limited Collections}

Specialized Collections

Retrospective Collection

\section{Newsletter Subscription}

Home Advanced Materials Research Editor Board

\section{Advanced Materials Research}

\section{Editor(s) in Chief}

\section{Prof. Xiao Zhi Hu}

Prof. Alan Kin Tak Lau

Prof. Prafulla K. Jha

Prof. Heinz Palkowski

Wolfgang Sand

Dr. Ching Hua Su

Editorial Board

\section{Dr. Peng Cao}

\section{SEND MESSAGE}

University of Western Australia, School of Mechanical and Chemical Engineering; Perth, Australia, WA 6009;

\section{SEND MESSAGE}

Swinburne University of Technology, Faculty of Science, Engineering and Technology; John Street, Hawthorn, Australia, VIC 3122;

\section{SEND MESSAGE}

University of Auckland, Department of Chemical and Materials Engineering; Private Bag, Auckland, New Zealand, 92019;

\section{SEND MESSAGE}

Technical University of Cluj-Napoca, Faculty of Materials and Environmental Engineering Department of Materials Science and Engineering; 103-105 Muncii Blv., Cluj-Napoca, 400641, Romania;

\section{SEND MESSAGE}

Maharaja Sayajirao University of Baroda, Department of Physics, Faculty of Science; Vadodara, India, 390 002;

\section{SEND MESSAGE}

Clausthal University of Technology, Institute of Metallurgy; Robert-Koch-Strasse 42, Clausthal-Zellerfeld, 38678, Germany;

SEND MESSAGE

University of Duisburg-Essen, Biofilm Centre, Aquatic Biotechnology; Geibelstrasse 41, Duisburg, 47057, Germany;

\section{SEND MESSAGE}

NASA/Marshall Space Flight Center, EM31 NASA/Marshall Space Flight Center; Huntsville, USA, 35812; 
Subscribe to our Newsletter and get informed about new publication regularly and special discounts for subscribers!

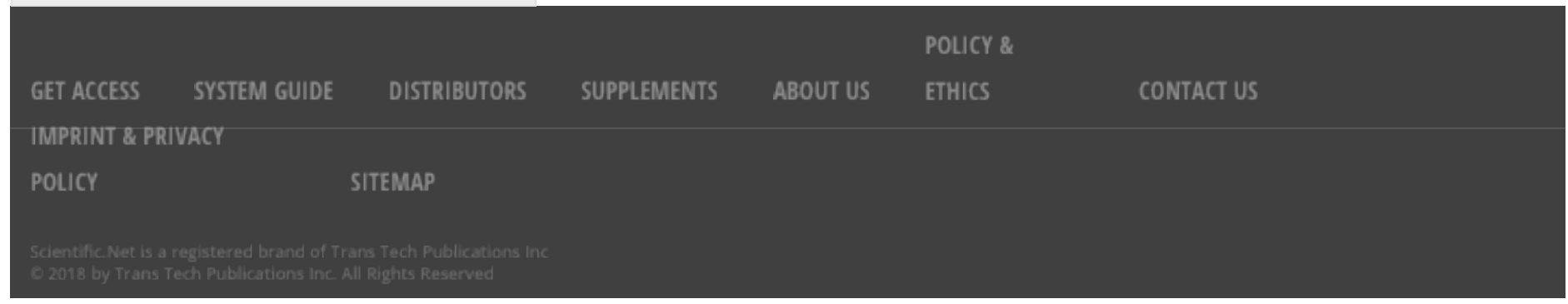




\section{Advances in Materials, Processing and Manufacturing}
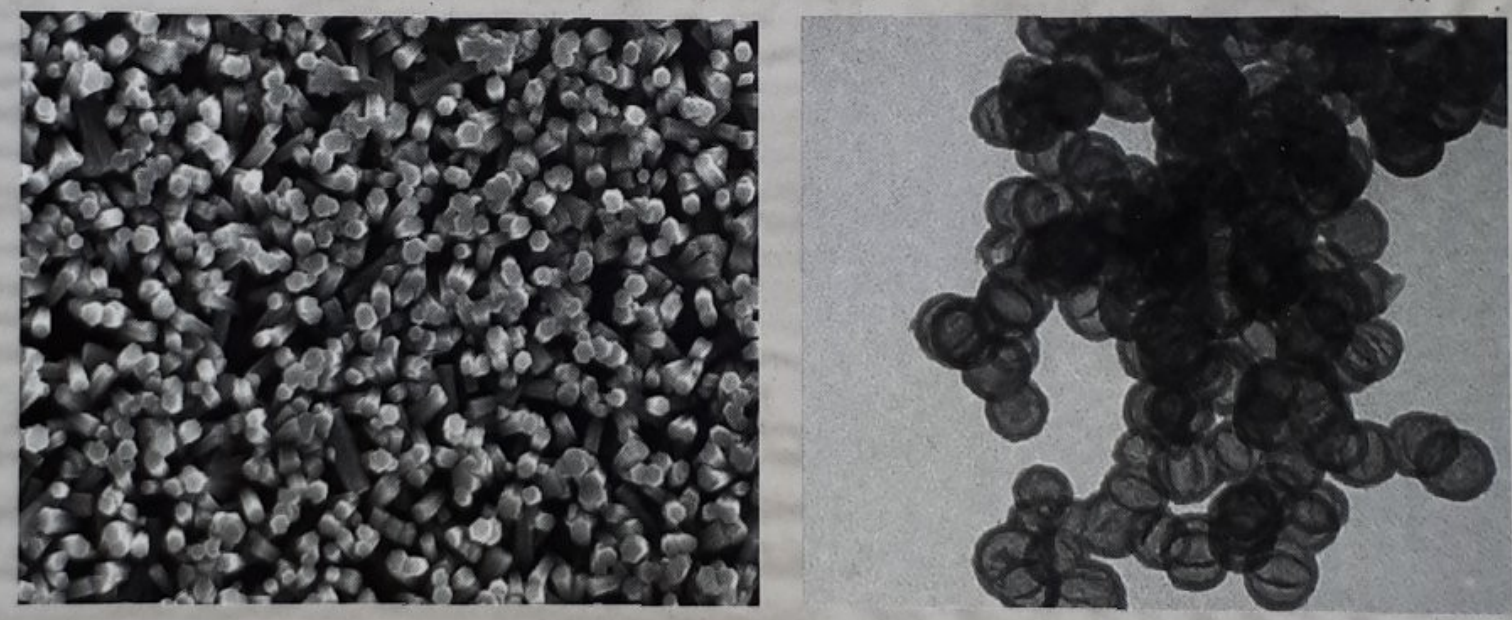

Edited by Akhmad Herman Yuwono 


\title{
Advanced Materials Research
}

ISSN: 1022-6680, ISSN/ISO: Adv: Mater. Res.

Edicors:

Niao Zhi Hu, The University of Westem Australia, School of Mechanical Engineering

Perth. Australia. xhu@mech.uwa.edu_au

Alan Kin Tak Lau. Hong Kong Polytechnic University. Department of Mechanical

Engineering. Hung Hom. Kowloon, Hong Kong. China P.R., mmktlau a polyu.edu.hk

Publishing Editor: Thomas Wohlbier, T., 105 Springdale Lane, Millersville. PA 17551, USA.

twohlbier@a ttp.net

\section{Editorial Board:}

Barton, J. University of Southampton, School of Enginerring Sciences. UK

Caa. P. University of Waikato. Department of Materials and Process Engineering. New Zealand

Chandra, T. University of Wollongong. Faculty of Engineering. Australia

Chicinas, 1., Technical University of Cluj-Napoca. Department of Materials Science and Technology, Romania

Daniel , B.S.S., Indian Institute of Technology Roorkee, Department of Metallurgical and Mat. Engineering, Centre of Nanotechnology,

India

Engel, U.. University of Erlangen-Nuremberg. Chair of Manufacturing. Erlangen-Nuremberg, Germany

Evans, S.L., Cardiff University, Cardiff Sehool of Engineering. UK

Gao, H., Dalian University of Technology, School of Mechanical Engineering. China P.R.

Ibhadode, A.O.A., University of Benin, Department of Production Engineering. Nigeria

Jha, P.K., Bhavnagar University, Department of Physics, India
Kim, J.K., Hong Kong University of Science and Technology, Department of Mechanical Engineering. China P.R.

Leng. J.S. Harbin Institute of Technology. Center for Composite Materials and Structures, China P.R.

Palkowski, H. Clausthal University of Technology. Institute of Metallurgy. Germany

Pallin. R., Cardiff University, Cardifr School of Engineering. UK

Sand, W., University of Duisburg-Essen, Biofilm Centre, Germany

Schikorra, M., University of Dortmund, Institute of Forming Technology and Lightweight Construction (IUL), Germany

Yin, Y.S., Shanghai Maritime University, Institute of Marine Materials Seience and Engineering. Cira P.R.

Zyang. D.L., University of Waikato, Department of Materials and Process Engineering.

New Zealand

Zhang. T.Y.. Hong Kong University of Science and Technology, Department of Mechanical Eng., China P.R.

\begin{abstract}
Aims and Scope:
Advanced Materials Research specializes in the very rapid publication of international conference proceedings and stand-alone volumes on topics of current interest in all areas of materials research and related topies.
\end{abstract}

\section{Internet:}

The periodical is available in full text via www.scientifc.net

\section{Subseription Information:}

Irregular; approx. 150-250 volumes per year. First volume in 2013: vol. 601

The subscription rate for web access is EUR 1070.00 per year. Standing order price: EUR 108.00 per volume including online access, EUR 100.00 per volume for print only. ISSN prim 1022-6680 ISSN od 1022-6680 ISSN web 1662-8985

\author{
Trans Tech Publications Ltd \\ Kreuzstr. 10 - 8635 Zurich-Durnten - Switzerland \\ Fax +41 (44) 9221033 - e-mail: ttpa ttp.net




\section{Advances in Materials, Processing and Manufacturing}

Edited by Akhmad Herman Yuwono 


\section{Advances in Materials, Processing and Manufacturing}

Selected, peer reviewed papers from the 13th International Conference on Quality in Research

(QiR 2013),

June 25-28, 2013, Yogyakarta, Indonesia

Edited by

Akhmad Herman Yuwono

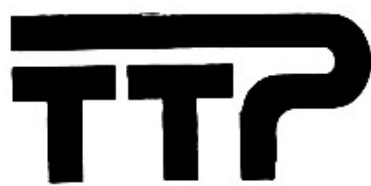


Copyright 12013 Trans Tech Publications Ltd, Switzerland

All rights reserved. No part of the contents of this publication may be reproduced or transmitted in any form or by any means without the written permission of the publisher.

Trans Tech Publications Ltd

Kreuzstrasse 10

$\mathrm{CH}-8635$ Durnten-Zurich

Switzerland

http://www.ttp.net

Volume 789 of

Advanced Materials Research

ISSN print 1022-6680

ISSN cd 1022-6680

ISSN web 1662-8985

Full text available online at $h t t p: / / w w w . s c i e n t i f i c . n e t$

Distributed worldwide by

Trans Tech Publications Ltd

Kreuzstrasse 10

$\mathrm{CH}-8635$ Durnten-Zurich

Switzerland

Fax: +41 (44) 9221033

e-mail: sales@ttp.net and in the Americas by

Trans Tech Publications Inc.

PO Box 699, May Street

Enfield, NH 03748

USA

Phone: +1 (603) 632-7377

Fax: +1 (603) 632-5611

e-mail: sales-usa@ttp.net

printed in Germany 


\section{Editorial Note}

Sustainable development is a central issue in today globalization era where human being always tries to increase its quality of life from time to time. The awareness of the impact of any aspects on the environment is essential. The fulfillment of human life quality, therefore, must be always balanced with its harmony with the nature. The $13^{\text {th }}$ International Conference on Quality in Research (QiR) 2013 held in Yogyakarta, Indonesia on June 25-28 2013, is aimed at bringing national and international front-liners, thinkers, academicians, executives, government and business officials, practitioners and leaders to present results of their ongoing research and to discuss a wide range of engineering, architectural and community development issues to explore innovation for enhancement of human life and environment.

In this edition of Advanced Materials Research journal, we are pleased to bring the selected collection of papers from the $13^{\text {th }}$ QiR conference in the area of Materials Engineering and related topics. All of the contributing papers in this book have been peer reviewed by expert referees in order to meet professional and scientific standards. Since the conference is planned to address a wide spectrum of materials engineering, therefore, this edition is divided into the following sections: (i) Advanced and Composite Materials; (ii) Polymer and Ceramic Materials; (iii) Materials Manufacturing and Processes; (iv) Corrosion and Degradation of Materials; and (iv) Extraction of Materials.

We do realize that the success of $13^{\text {th }}$ International Conference on Quality in Research (QiR) 2013 and the publication of this book are derived from the very hard work of lots of people. Therefore, we would like to thank all of the authors who have spent their time to contribute with their genuine results, and all of the reviewers for their valuable dedication, time and comments to ensure the published papers have reached the international journal standard. We also would like to take this opportunity to thank many people and organizations who have supported this conference. Finally, we hope that this book will serve as a good archive of research findings and provide useful directions for future research.

Editor-in-chief

Akhmad Herman Yuwono 


\title{
Table of Contents
}

\author{
Editorial Note
}

\section{Chapter 1: Advanced and Composite Materials}

Atomic Layer Deposition of Inverse Opals for Solar Cell Applications

S.K. Karuturi, L.J. Liu, L.T. Su, W.B. Niu and A.L.Y. Tok

The Influence of Various Percentage of $\mathrm{Al}_{2} \mathrm{O}_{3}$ by Using Vortex Method to Tensile

Strength and the Distribution of $\mathrm{Al}_{2} \mathrm{O}_{3 \mathrm{p}}$ Composite

S. Junus, A. Zulfia, E. Tanoto and L. Mariani.

Modifications of Multi-Walled Carbon Nanotubes on Zinc Oxide Nanostructures

for Carbon Monoxide (CO) Gas Sensitive Layer

M. Iqbal, B. Yuliarto and N. Nugraha

An Investigation of Structure and Complex Impedance Behavior of Composite

$(1-X) B_{0.5} \mathrm{SR}_{0.5} \mathrm{FE}_{11.7} \mathrm{MN}_{0.15} \mathrm{TI}_{0.15} / X \mathrm{LA}_{0.7} \mathrm{BA}_{0.3} \mathrm{MNO}_{3}$

V.V.R. Repi and A. Manaf.

Electrochemical Behavior of $\mathrm{Li}_{4} \mathrm{Ti}_{5} \mathrm{O}_{12}$ under In Situ Process of Sintering and

Surface Coating with Cassava Powder

B. Prihandoko, A. Subhan and S. Priyono

Synthesis of Highly-Ordered $\mathrm{TiO}_{2}$ through $\mathrm{CO}_{2}$ Supercritical Extraction for

Dye-Sensitized Solar Cell Application

B. Priyono, A.H. Yuwono, B. Munir, A. Rahman, A. Maulana and H. Abimanyu

Deformation Behaviour of Silicon Carbide Reinforced Al-7Si Composite after

Balistic Impacts

B.T. Sofyan, D. Rahmalina, B. Suharno and E.S. Siradj

Hydrogen Absorpsivity-Desorbsivity of $\mathrm{Mg}$ Doped by $\mathrm{Ni}, \mathrm{Cu}, \mathrm{Al}$ Produced by

Mechanical Alloying

W. Widyastuti, B.P. Febrian and S. Sutarsis.

Crystallite Growth Kinetics of $\mathrm{BaFe}_{12} \mathrm{O}_{19} / \mathrm{SrTiO}_{3}$ Based Composites Derived from

Mechanical Alloying

R.D. Widodo, A. Manaf and P. Sardjono

Crystal Structures and Thermal Properties of Bamboo Nanofiber Reinforced-

Composite Friction Materials of Glass and Metal Wastes

S. Madnasri, S.S. Edi and D.S. Saputra

Formation and Characterization of MMCs Alloy $\mathrm{Al}-5 \% \mathrm{Cu}-4 \% \mathrm{Mg} / \mathrm{SiC}(\mathrm{p})$ by

Thixoforming Process

Y. Afandi, A. Zulfia, D. Priadi and I.N. Jujur.

Study on PbSn Composites Produced by Powder Metallurgy as Core

Bullet Projectile

W. Widyastuti, V.A. Setyowati and T. Akbar 60

Electroless Plating of $\mathrm{Al}_{2} \mathrm{O}_{3}$ Particles Reinforced Composites

A. Zulfia and A.I. Adyatma 
Characterization of Al-7Si-Mg-Cu Turbine Impeller Produced by Investment Casting

M. Syahid, B.T. Sofyan, S.G. Basuki and B. Adam

Research on the Manufacturing of Steam Turbine Blade by Using Investment

Casting Technology

Hafid.

Mechanical Properties and Microstructure of Welded Dissimilar Metals Using

Buttering \& Non-Buttering Layer

W. Winarto. M. Anis and T.P. Hertanto

Comparison of Commercially Pure Titanium Surface Hardness Improvement by

Plasma Nitrocarburizing and Ion Implantation

A.S. Darmawan, W.A. Siswanto and T. Sujitno

Effect of Phenolic Resin and Alignment to the Quality of Prototype Composite

Railway Brake Blocks

A. Triono, W.P. Ign, S.S. Brodjonegoro and A. Ramelan

Effects of Welding Parameters in Micro Friction Stir Lap Welding of

Aluminum A1100

A.S. Baskoro, A.A.D. Nugroho, D. Rahayu, Suwarsono, G. Kiswanto and W. Winarto

Preparation of Uranium Nitride from Uranium Metal through by Hydriding and

Nitriding Process

H. Suwarno

Simulation of Metal Flow to Investigate the Application of Antilock Brake Mechanic System in Deep Drawing Process of Cup

S. Candra, I.M.L. Batan, A.S. Pramono and B. Pramujati

Effect of Equal Channel Angular Pressing and Post Heating on Microstructure and

Hardness of $\mathrm{Cu}-\mathrm{Zn} \mathrm{70/30}$

S. Suryadi, R.A.M. Napitupulu, D. Priadi, A. Suhadi and E.S. Siradj

Materials Selection in Appropriate Technology Four Focuses in Design Thinking

C.P.M. Sianipar, H. Taufiq, H.R. Estiningtyas, K. Dowaki,

A. Adhiutama and G. Yudoko

Study about Surface Hardening on Local Disc Brakes with Direct Current Plasma

Nitrocarburizing Apparatus

U. Sudjadi

The Effect of Vertical Step Block Casting to Microstructure and Mechanical

Properties in Producing Thin Wall Ductile Iron

R.D. Sulamet-Ariobimo, J.W. Soedarsono and I.P. Nanda

Resolving Individual Solute Levels of AA6061 through Multiple Sub-Ambient

Temperatures Thermoelectric Power Measurements

D.D. Risanti and S. van der Zwaag

Effect of Rolling Direction to the Strength of a Thin-Walled Steel SHS Beam under Concentrated-Compressive Load and Bending Moment

A.M. Kadir, D. Priadi, E.S. Siradj and H. Setiyono

Optimization Design of Airfoil Propellers of Modified NACA 4415 Using

Computational Fluids Dynamics

Sudarsono, Purwanto and J. Wahyuadi.

Analysis of Micro-Channels Manufacturing of Acrylic Using Low Power $\mathrm{CO}_{2}$ Laser

A.S. Baskoro, A. Siswanta and K.G.S. Ismail 


\title{
Simulation of Metal Flow to Investigate the Application of Antilock Brake Mechanic System in Deep Drawing Process of Cup

$$
\begin{array}{r}
\text { Susila Candra }{ }^{1, a} \text {, I Made London Batan }{ }^{1, b} \text {, Agus Sigit } P^{1, c} \text {, } \\
\text { Bambang Pramujati }{ }^{1, d}
\end{array}
$$

\author{
${ }^{1}$ Mechanical Engineering, Institute of Technology Sepuluh Nopember (ITS), Indonesia \\ asusilac@yahoo.com, ${ }^{\mathrm{P}}$ Iondbatan@me.its.ac.id, ${ }^{\mathrm{c}}$ pramono@me.its.ac.id, ${ }^{\text {d }}$ pramujati@me.its.ac.id
}

Keywords: deep drawing, metal flow, blank holder force, antilock brake system, cracking.

ABSTRACT This paper presents the importance of simulation of metal flow in deep drawing process which employs an antilock brake mechanic system. Controlling the force and friction of the blank holder is imperative to assure that the sheet metal is not locked on the blank holder, and hence it flows smoothly into the die. The simulation was developed based on the material displacement, deformation and deep drawing force on flange in the radial direction, that it is controlled by blank holder with antilock brake mechanic system. The force to blank holder was applied periodically and the magnitude of force was kept constant during simulation process. In this study, the mechanical properties of the material were choses such that they equivalent to those of low carbon steel with its thickness of $0.2 \mathrm{~mm}$. The diameter and the depth of the cylindrical cup-shaped product were $40 \mathrm{~mm}$ and $10 \mathrm{~mm}$, respectively. The simulation results showed that the application of antilock brake mechanic system improves the ability to control the material flow during the drawing process, although the maximum blank holder force of $13000 \mathrm{~N}$ was applied. The optimum condition was found when the drawing process was performed using blank holder force of $3500 \mathrm{~N}$, deep drawing force of $7000 \mathrm{~N}$, friction coefficient of 0.25 and speed of punch stroke of $0.84 \mathrm{~mm} / \mathrm{sec}$. This research demonstrated that an antilock brake mechanic system can be implemented effectively to prevent cracking in deep drawing process.

\section{Introduction}

A drawing process refers to a sheet metal forming process where a sheet metal is radially drawn into a forming die by implementing a mechanical action of punch. It is called "deep drawing" when the depth of the drawn part exceed the diameter of the product. Although this process has been known and used for many years, there are many problems that may occur during the process and still become the attraction of many researchers. The process of deep drawing and problems that often occur in this process are illustrated in Figure 1.

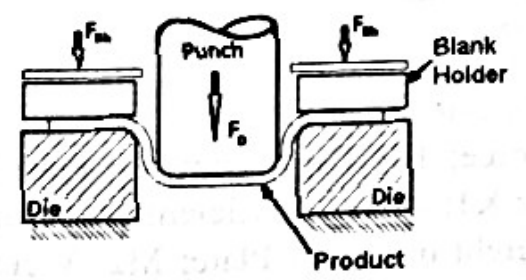

(a)

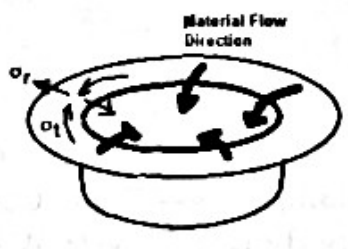

(b)

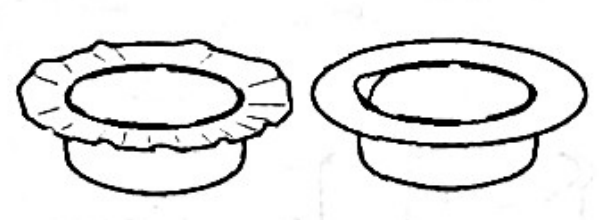

(c)

Figure 1. (a) Process of drawing deep; (b) Flow of material and stress deformation; (c) Crack and wrinkle defect.

Controlling the flow of material properly during a deep drawing process is very important in order to prevent product defects such as wrinkling and cracking. Endelt, B [1] investigate the application of a flexible blank-holder system to adjust the blank-holder pressure individually in different zones in the flange area [1]. The draw-in of the flange is influenced by the blank-holder pressure and therefore, the draw-in can be controlled by adjusting/controlling the pressure. Online 
drawn-in measurement can be performed using laser technology in which its sensors based on mechanical devices. However, this method requires sensors and equipment that are not applicable to the industry.

The magnitude of the blank holder force is an important factor in the forming process and hence the proper magnitude has to be determined properly. In this study, a variable blank holder force (VBHF) approach to deep drawing is employed [2][5][6]. This study provides information about the optimal gap to prevent wrinkling of the material, which will be used as data in this simulation. It was found that the optimal gap is no more than $117 \%$ the thickness of the material [2].

Gavas, M., studied the use of a simple mechanical antilock brake system (ABS) to control the material flow in deep drawing process [3][4]. The experiment proved that the additional mechanism helps to ease the flow of the material into the die yield to the possibility of deeper drawing process. However, the importance stage prior to experimental process, i.e. simulation, was not performed. Therefore, investigating various materials having different material properties as well as dimensions would be very difficult and expensive. It is due to different arrangement of system and most likely different equipment are needed in order to perform such different experiment set-up and test.

Based on the description above, it is clear that the control of blank holder force is an important parameter that must be considered. Therefore this paper will discuss about the application blank holder with anti lock brake system, in order to further optimize the flow of material towards the radial (not locked) and tangential (not too fast). The results of this study present the material flow simulations using a blank holder with antilock brake system, as has been done by M Gavas [4]. Validation of the method by comparing the simulation results with Gavas's experiment, related to the condition of material flow and material formability.

\section{System Equation}

Simulation model of anti-lock system in the process of deep drawing requires the development of material flow equations between the surface of the die and blank holder, the function of blank holder force and the condition of the process. The free body diagram (FGD) of deep drawing process and product dimensions are illustrated in Figure $2 \mathrm{a}$ and $2 \mathrm{~b}$, respectively.
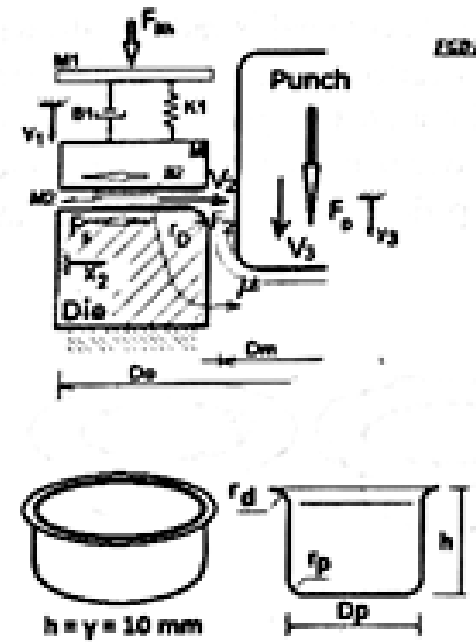

b $\operatorname{csed}$

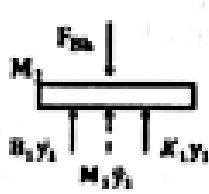

tor

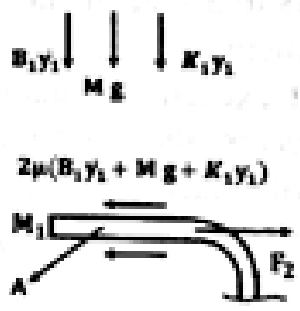

a
EcoIII

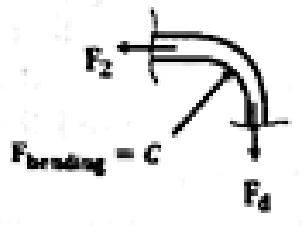

Figure 2.a. FGD of deep drawing on cylindrical products, b. Product dimensions

Based on FGD 1 in Figure 2.a. the equation of blank holder force can be determined as follows:

$$
F_{\mathrm{gb}}=M_{1} \ddot{y}_{1}+B_{1} \dot{y}_{1}+K y_{1}
$$


Fon represents the force that controls the flow of metal into the die. The magnitude of restraining force (F2) can be drawn from the equilibrium of force in llange as shown in F(iD II of Figure 2.a.

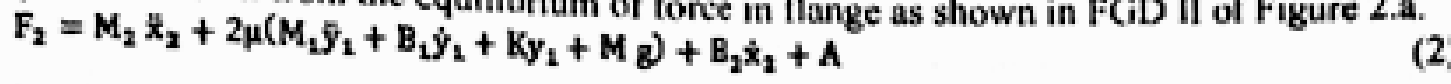

Here, the variable " $\mathrm{A}$ " is the ideal stress deformation (deformation factor), which is obtained from the following equation:

$$
A=\pi \cdot D_{m} \cdot S_{0} e^{\mu \pi / 2}\left\{1.15 \sigma_{0}\left(\frac{\underline{x}_{2}}{T_{m}}\right)\right\}
$$

where, $\sigma_{0}$ is the material yield stress, $D_{0}$ is the initial blank diameter, $D_{m}$ is the mean diameter, $s_{0}$ is the thickness of material; $\mu$ is the coefficient of friction and $x_{2}$ is the position of material flows for a moment after pressure is applied.

Deep drawing force is the sum of tensile force on the flange and bending force on die radius, and therefore, the equation of deep drawing force is:

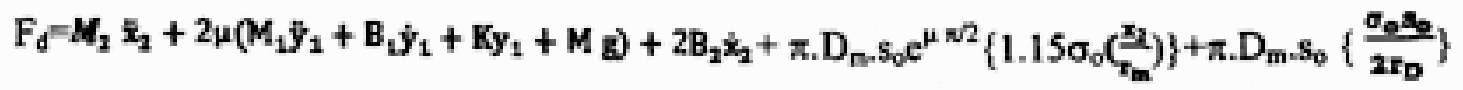

Having $\sigma_{\circ}=309 \mathrm{~N} / \mathrm{m}^{2}, \mathrm{D}_{\mathrm{o}}=56,7 \mathrm{~mm} ;$ ro $=28.35, \mathrm{D}_{p}=40 \mathrm{~mm} ; \mathrm{s}_{0}=0.2 \mathrm{~mm} ; \mathrm{D}_{\mathrm{m}}=\mathrm{Dp}+\mathrm{s}_{\mathrm{o}}=40.2 \mathrm{~mm}$; $\mathrm{rD}_{\mathrm{D}}=$ die radius $=1 \mathrm{~mm}$, substituting equation $(1)$ into (4), the movement of flange modeling yields:

$$
\bar{x}_{2}=\frac{1}{M_{2}}\left\{F_{d}-2 \mu\left(M_{1} \hat{y}_{1}+B_{1} \dot{y}_{1}+K y_{1}+M g\right)-2 B_{2} \dot{x}_{2}-446.32 \theta^{2.57 \mu}\left(x_{2}\right)-780.07\right\}
$$

Equation (5) is used as a mathematical model of the simulation system for the application of blank holder by using antilock braking mechanic system.

The flow of material on the surface of the flange and into the die follows the rule of constant volume, and the following relationship can be obtained:

and then,

$$
x_{2 d}=\frac{1}{a s} x_{2} \text { and } V_{2 d}=\frac{1}{a s} V_{2}
$$

$$
\mathrm{y}_{34}=0.8 \mathrm{x}_{2 \mathrm{~d}} \text { and } \mathrm{V}_{3 \mathrm{~d}}=0.8 \mathrm{~V}_{2 \mathrm{~d}}
$$

Deep Drawing Equipment With Antilock Brake System Application [3][4]

The design and the development of deep drawing with the anti lock brake mechanic system is shown in Figure 3 [3][4].

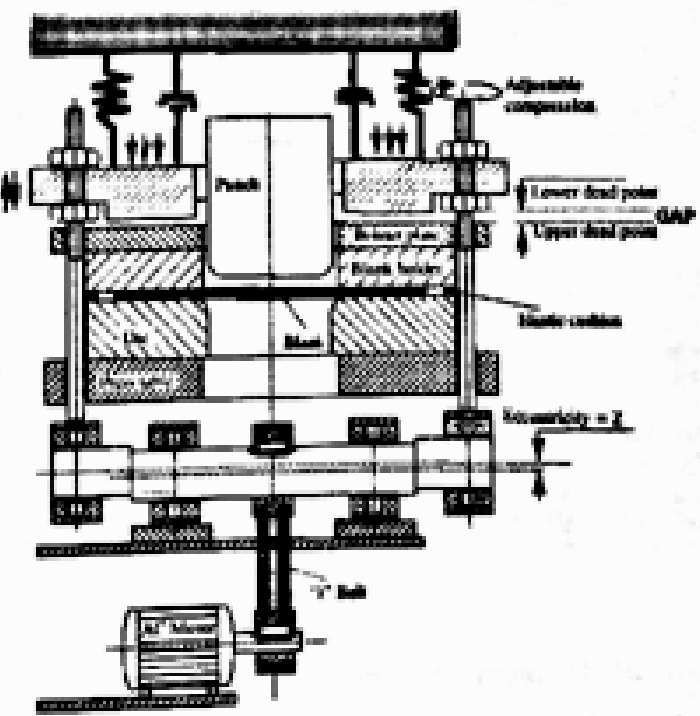

Figure 3 Scheme of deep drawing machine using application of blank holder with anti lock brake system [3][4] 
If the path of shaft in the radial direction of eccentric was approached with a sinusoidal equation, therefore eccentricity $\mathrm{Z}$ can be described as an amplitude. While setting the distance gap represents a shift graphic of sinusoidal up and down. therefore the sinusoidal trajectory of eccentric axis would represent the mechanism of anti lock braking/hammering mechanic system. And with these mechanisms system, the deep drawing force (Fd) can be modelled independently. As well as the simulation modelling would describe the influence of blank holder Force (Fbh) against the movement of flange and the metal forming. Then, refers to the equation (5) above and the mechanism of anti lock brake system, furthermore the algorithm programming/ simulation block diagram is created.

\section{Block and Computer Simulation}

A block diagram for dynamic simulation of the mechanism of anti-lock brake system can be formed using equations 4 and 5 , and the results are illustrated in Figure 4.a. The model parameters used for simulation are given below.

\begin{tabular}{|ll|}
\hline Meterial of blank sheet: low carbon steel sheet; & $\mu=$ coefficient of friction $=0.25$ (palm oil) \\
Gap $= \pm 5 \mathrm{~mm}$ following reference [1] and [2]; & $\mathrm{x}_{2}=$ The position of flange \\
$\mathrm{M} 2=1 \mathrm{~N}$ (weight of blank sheet); & $\mathrm{M}_{1}=500 \mathrm{~N}$ (weight of blank holder plate) \\
$\mathrm{B}_{1}=600 \mathrm{Ns} / \mathrm{mm}$ (value of damping coefficient); & $\mathrm{B}_{2}=100 \mathrm{Ns} / \mathrm{mm}$ (value of damping coefficient on flange surface) \\
$\mathrm{K}_{1}=1000 \mathrm{~N} / \mathrm{mm}$ (value of spring coefficient); & $\mathrm{F}_{\mathrm{a}}=3500 \mathrm{~N} ; \mathrm{Fd}=7000 \mathrm{~N}$ (average of Deep Drawing Force) \\
$\sigma_{0}=309 \mathrm{~N} / \mathrm{m}^{2} ;$ & $\mathrm{D}_{0}=56.7 \mathrm{~mm} ; \mathrm{r}_{0}=28.35 ; \mathrm{D}_{\mathrm{s}}=40.2 \mathrm{~mm}$ \\
$\mathrm{~s}_{\mathrm{o}}=0.2 \mathrm{~mm} ; \mathrm{r}_{\mathrm{D}}=$ die radins $=1 \mathrm{~mm} ;$ & $\mathrm{Dp}_{\mathrm{p}}=40 \mathrm{~mm}$ \\
\hline
\end{tabular}

Figures 4.b and 4.c show the simulation result of deep drawing process, i.e. the blank holder displacement and velocity, respectively. It can be seen that both displacement and velocity of blank holder when the drawing process is performed using anti lock brake system are lower than it is performed without anti lock mechanism. It is due to the fact that the application of anti lock mechanism allows the metal to flow more freely since the magnitude of displacement and velocity are influenced by the applied force on the blank holder.
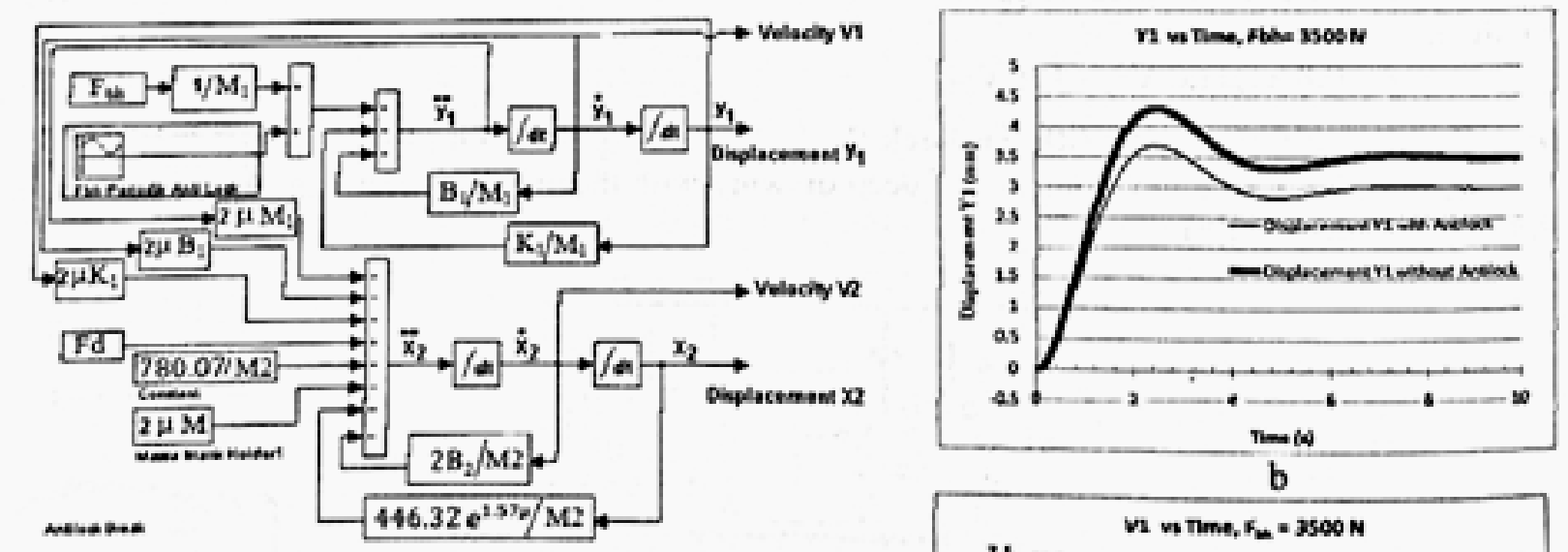

b

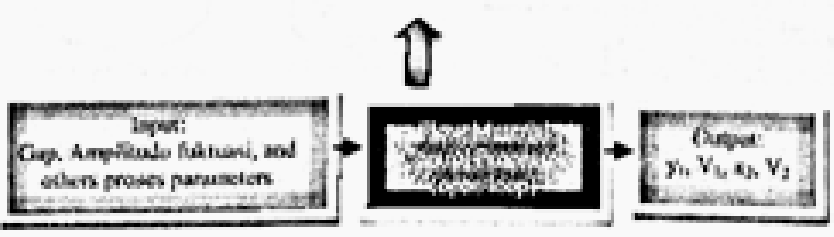

a.

c.

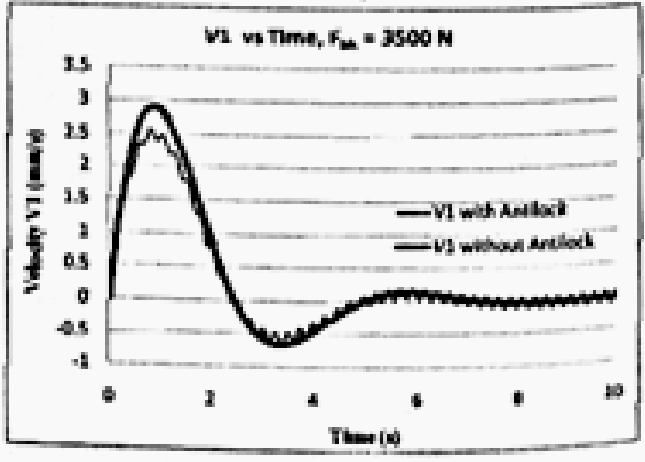

Figure 4.a. Block diagram of simulation the material flow by using the antilock brake systems, b and $c$. Displacement $y_{1}$ and velocity $V_{1}$. 


\section{Results and Discussions}

Figure 5 illustrate the simulation of the drawn material which it flows is not obstructed when the antilock braking system is used in the system. The results show that the material displacement (x2) on the flange reach approximately $6.9 \mathrm{~mm}$ and the speed of punch stroke of $0.84 \mathrm{~mm} / \mathrm{sec}$. It can be observed that the displacement of the flange can only reach less than $6.4 \mathrm{~mm}$ when the antilock braking system is not employed. Increasing in flange displacement lead to increasing in material formability, and in this case, the formability increases by $30 \%$. Similar results were indicated by Gavas's experiment [3][4]. He also proved that the applications of antilock braking system blank holder yields increases of material formability.
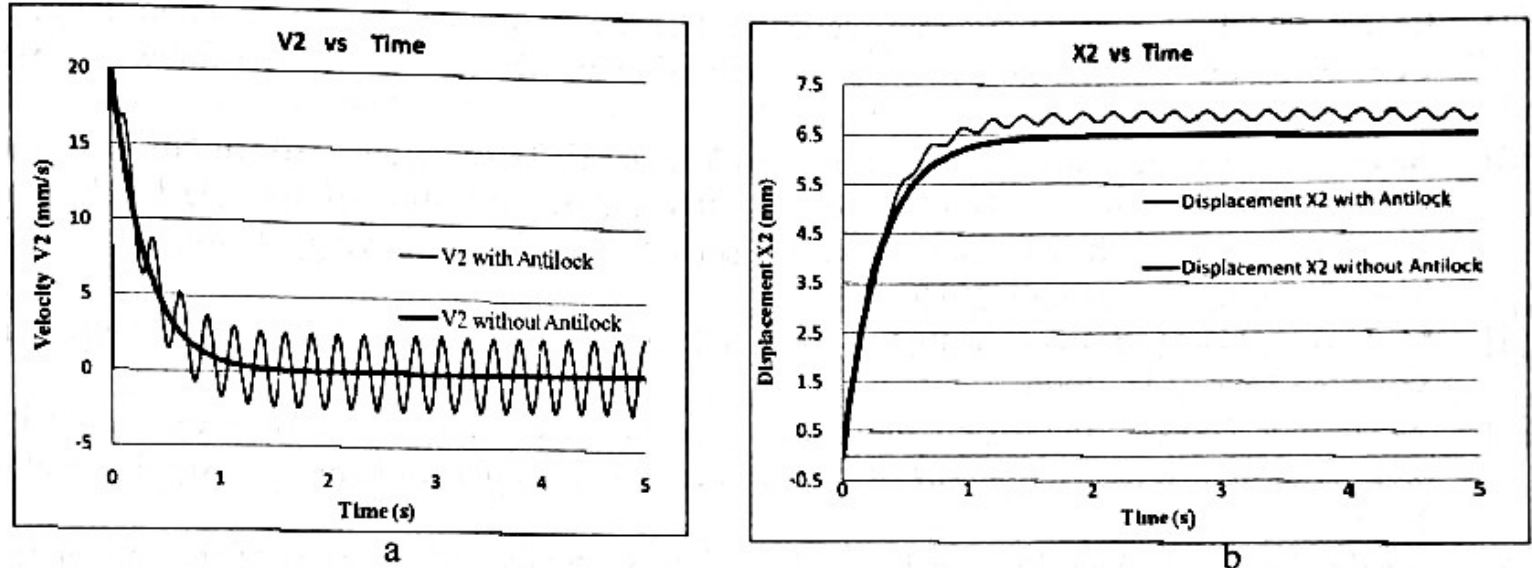

Figure 5. a. The Graphic of velocity (on Blank Holder) $V_{2}$ with and without antilock;

b. Displacement graphic of sheet material in the flange $\left(\mathrm{x}_{2}\right)$

Figure 6 shows that although the applied holder force reaches its highest magnitude of 13000 $\mathrm{N}$, the antilock braking system still quite effective to avoid locking in the material flow. It means that the system is capable of controlling flow of material under a very high holding force. In order to optimize the application blank holder on this system, and to improve the ability to avoid locking in the flow of materials, the gap between the upper dead point and lower dead points (see Figure 3) shall be adjusted properly. All the simulations results above agree with the experiment of application anti-lock brake system that was performed by Gavas [3][4], and hence his method can be considered feasible for production.
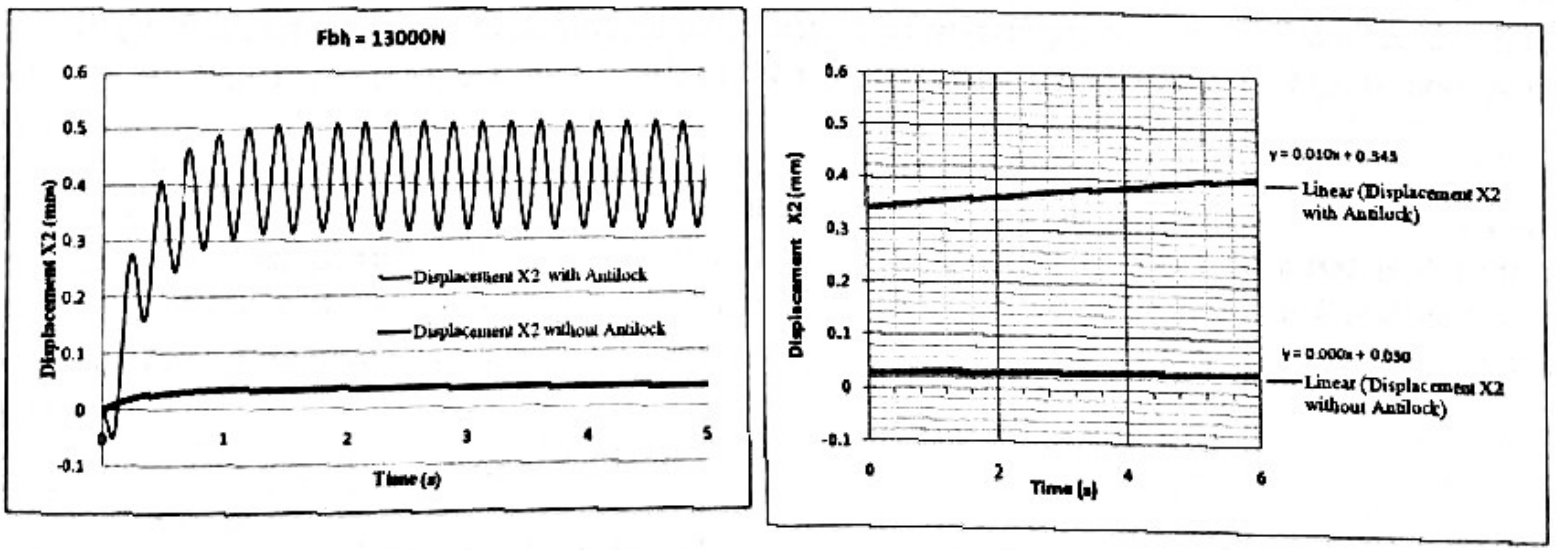

Figure 6. The Displacement of material in the flange $\left(x_{2}\right)$ with the magnitude of $F_{b h} 13000 N$.

\section{Summary}

The application blank holder with antilock brake systems to control the material flow is one of the alternative methods to prevent sheet material to wrinkle and/or crack. The simulation results showed that these system capable of controlling the flow of material smoothly even though the 
value of blank holder force reaches the maximum value of $13000 \mathrm{~N}$. It was suggested that the optimum value of blank holder force is set approximately $3500 \mathrm{~N}$, deep drawing force of $700(0) \mathrm{N}$ friction coefficient of 0.25 and speed of punch stroke of $0.84 \mathrm{~mm} / \mathrm{sec}$. The anti-lock brake system would increas the material formability up to $30 \%$. An open loop brake mechanics system has been implemented, however several drawbacks were noticed. The simulation results also showed that a closed loop system can be employed to improve the performance of the implemented open loop brake mechanics system.

\section{References}

[1] Benny Endelt, Soren Tommerup, Joachim Danckert, A novel feedback control systemControlling the material flow in deep drawing using distributed blank-holder force, Journal of Materials Processing Technology, 2013.

[2] Satoshi Kitayama, Satoshi Hamano, Koetsu Yamazaki, Tatsuo Kubo, Hikaru Nishikawa and Hiroshi Kinoshita A closed-loop type algorithm for determination of variable blank holder force trajectory and its application to square cup deep drawing, Jaurnal of Adv. Manufacturing Technology 2010.

[3] M. Gavas, "Deep drawing with anti-lock braking system (ABS)", Journal Mechanism and Machine Theory 41, 2006.

[4] Muammer Gavas, "Increasing the drawing height of conical square cups using anti-lock braking system (ABS)", Journal of Mechanical Science and Technology 23 page3079 3087, 2009.

[5] Susila Candra, I Made Londen Batan, Experimental Study and Analysis of the Influence of Drawbead against Restriction and Deep Drawing Force of Rectangular Cup-Cans with Tin Plate Material, 3rd International Conference on Mechanical and Manufacturing Engineering 2012, (ICME2012) UTHM Malaysia, and published online, in Journal of Applied Mechanics and Materials Vol.315 pp 246-251, Trans Tech Publications, Switzerland, doi:10.4028/www.scientific.net/ AMM.315.246, 2013.

[6] Susila Candra, Dedi Priadi, Henky S Nugroho, Analysis of The Influence of Drawbead and Parameters Process on The Establishment of Rectangular-Can with The Material T4 CA-B Tin Plate, Thesis Master Degree, Mechanical Engineering, University of Indonesia, 2002.

[7] Kurt Lange: "IIand Book Of Metal Forming", Mc Graw Hill Co. 1985. 
Figure description: (Left) SEM image of $\mathrm{ZnO}$ nanorod on ITO substrate for dye sensitized solar cell application;

(Right) TE image of mesoporous silica for drug delivery application

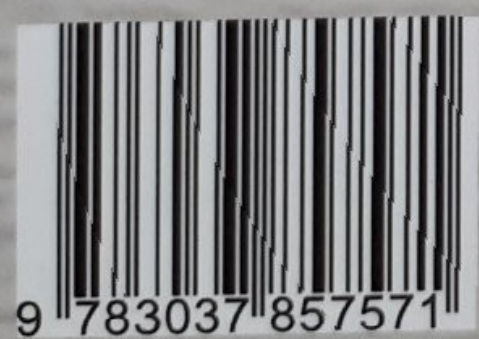

ISBN-13: 978-3-03785-757-1

Advanced Materials Research Vol. 789

Electronically available at $h t t p: / / w w w . s c i e n t i f i c . n e t$ 